\title{
Effect of Levels of Nitrogen Fertilizers and Intra Row Spacing on Growth Performance of Potato (Solanum Tuberosum) at Wolaita, Southwestern Ethiopia
}

\author{
Tigist yisahak Asrat Abere \\ Department of Horticulture, Wolaita Sodo University, Sodo, Ethiopia, P.O.BOX 138, WolaitaSodo,Ethiopia
}

\begin{abstract}
A field experiment was conducted at the experimental site of Wolaita sodo Universit Colleg of Agriculture during 2017 cropping season the objective of this study was to examine effects of level of nitrogen and intra row spacing on growth of potato. The experiment was conducted on a randomized complete block design with three replications. The result of the experiment revealed significant difference among treatments with regard main stem number, plant height, leaf area, days 50\% flowering, shoot fresh weight, total dry weight at $(\mathrm{p}<0.05)$. While the combined effect of Nitrogen fertilizer and spacing have no significant among treatments at $(\mathrm{p}<0.05)$. maximum growth of potato were observed for all treatments at the application rate of $138 \mathrm{~kg}$ nitrogen per hectare and $50 \mathrm{~cm}$ intra row spacing except main stem number $(10.22)$ which is at $30 \mathrm{~cm}$, However the results of the experiment did not include yield components. Thus, a similar research should be conducted so as to assure the results of this experiment and to include yield components.
\end{abstract}

Keywords : Potato, Nitrogen Fertilizer, Intra Row Spacing, Experiment, Significant

DOI: $10.7176 / \mathrm{JBAH} / 10-14-02$

Publication date:July $31^{\text {st }} 2020$

\section{INTRODUCTION}

Potato (SolanumtuberosumL.) is the fourth most important food crop in the world following rice, corn and wheat (Horton, 1987).It is a staple food crop in some countries and in others it is used as vegetable (Zamilet al, 2010). According to the quantity of production and consumption worldwide, potato is the most important vegetable crop (FAO, 2008). In the world potato is grown in more than 125 countries (FAO, 2008). It is the second only to Maize in terms of the number of producer countries. Potato was introduced to Ethiopia in 1858 by the German Botanist, Schemper (Visker,2005).

Potato cultivars are utilized according to the end-use product that they are destined for households, firm potato cultivars such as BP1 and Vander plank are favored when making salads because they do not break easily, but the Up-to-Date cultivar is favored for mashing and baking because it is brittle(Visker,2005). Nutritional quality of potatoes is an ingredient in many dishes and salads. Potatoes are non-fattening, nutritious and wholesome food that supplies many important nutrients to the diet (Oliveira, 2000).

Potatoes contain approximately $78 \%$ water, $22 \%$ dry matter and less than $1 \%$ fat. About $82 \%$ of dry matter is carbohydrate, mainly starch, with some dietary fiber and small quantities of various basic sugars. It is a major source of inexpensive energy, and contains high levels of carbohydrates and significant amounts of vitamins Band $\mathrm{C}$ and other minerals. Moreover, potato is used in many industries, such as French fries, chips, starch and alcohol production (Oliveira, 2000).

\subsection{Statement of problem}

Potato is grown in most parts of the world and also grown in some parts of our country but different factor affects the growth and developments of potato productions such as weed, climate, disease, and spacing and fertilizer application. Among those factors, intra row space and fertilizer application are the major critical problems in production of potato. The needs for fertilizer application depend on mainly on soil condition.

The level of nitrogen fertilizer is very determined to optimum growth of potato. In addition of this the intra row space also determinant to optimum growth of potato. To this purpose this experiment will be conducted to overcome or will help in exploring correct level of nitrogen fertilizers and intra row spacing to improve soil fertility and the problem related with different potato growth. The result of this experiment will be also to solve the problem with the fertilizer and intra row spacing requirements.

\subsection{Objectives}

\subsubsection{General objective}

- To evaluate the effects of level of nitrogen and intra row spacing on growth of potato.

\subsubsection{Specific objective}

- $\quad$ To determine the effects of nitrogen fertilizer rates and intra-row spacing on growth of potato.

- To identify the optimum levels of $\mathrm{N}$ fertilizer and intra-row spacing for better growth of potato. 


\section{MATERIALS AND METHODS}

\subsection{Description of the study area}

The experiment was conducted at wolaita sodo University in the year 2017 under supplementary irrigation. It is located in southern part of Ethiopia about $390 \mathrm{~km}$ far from Addis Ababa and it located geographically at altitude of $1800 \mathrm{~m}$ a.s.1, $6049 \mathrm{~N}$ and $37^{\circ} 45^{\prime} \mathrm{E}$ with annual mean temperature and rain fall of $200 \mathrm{c}$ and $1212 \mathrm{~mm}$ respectively (WSU student hand book, 2009)

\subsection{Treatments and Experimental design}

The treatments (Table 1) included factorial combinations of three levels of nitrogen $(0,69,138)$ and three levels of intra-row spacing $(30,40,50)$. The experiment was laid out in a randomized complete block design (RCBD) with three replications.

Table 1.Treatment combination were used in the experiment

\begin{tabular}{lll}
\hline Nitrogen levels $(\mathrm{N})(\mathrm{kg} / \mathrm{ha})$ & $\begin{array}{l}\text { Intra-row spacing (IS) } \\
(\mathrm{cm})\end{array}$ & Treatment combinations (N,IS) \\
\hline 0 & 30 & 0,30 \\
& 40 & 0 '40 \\
6 & 50 & 0,50 \\
69 & 30 & 69,30 \\
& 40 & 69,40 \\
138 & 50 & 69,50 \\
& 30 & 138,30 \\
& 40 & 138,40 \\
\hline
\end{tabular}

\subsection{Experimental material and procedure}

The materials that used during field work were Shovel, Meter, Digger, UREA fertilizer, Rope, Rack, potato tuber, water spray jars, $18.5 \mathrm{~m}$ x 5m land and in Laboratory were dry Oven scientific balance note book, pencil, pen, calculator. The planting material was potato tuber.

Land preparation done using human labor. The potato tubers were sown on a well prepared seed bed. The spacing between rows and plant was $30 \mathrm{~cm} \times 30 \mathrm{~cm}, 30 \mathrm{~cm} \times 40 \mathrm{~cm}$ and $30 \mathrm{~cm} \times 50 \mathrm{~cm}$. The spacing between plots and adjacent replication were $0.5 \mathrm{~m}$. The amount of nitrogen fertilizer was that $0 \mathrm{~kg} / \mathrm{ha}, 69 \mathrm{~kg} / \mathrm{ha}$ and $138 \mathrm{~kg} / \mathrm{ha}$ in the form of urea were supply in spliced way at the optimum growth stage. All experimental plots were received the recommended cultural practices. The source of nitrogen was Urea. The fertilizer was applied during sowing and two weeks after seedlings were raised by side dressing method of fertilizer application. Other cultural practice like watering, weeding and cultivation were done as recommended for the area. The area of one plot was $1.5 \mathrm{mx} 1 \mathrm{~m}$ was $1.5 \mathrm{~m}^{2}$. There were four rows per plot with twelve, sixteen and twenty plants in which $30 \mathrm{cmx} 30 \mathrm{~cm}, 30 \mathrm{~cm} x 40 \mathrm{~cm}$ and $30 \mathrm{~cm} \times 50 \mathrm{~cm}$ plot respectively that made up of the total number of plants were 145 .

\subsection{Data collected during the expermet}

Five randomly selected plants from the two middle rows of each experimental plot were tagged and used for recording data. The detailed methodology was adopted for collection of different data was as follows.

Plant height (m): was measured from the base of the soil surface to the tip of the plant at 50 percent flowering stage with meter.

Number of main stem: was obtained with counting the number of main stem of the plant.

Leave area (cm): was measured the area of leaves by square method.

Days to 50\% flowering: was obtained with counting the number of flowers of the plant.

Shoot fresh weight (g): was weighted with beam balance the shoot fresh masses of the selected plants (vine, leaf, branches).

Total dry weight: was measured with drying the five plants evaluated their fresh weight in an oven at $80{ }^{\circ} \mathrm{c}$ for 24 hours.

\subsection{Data analysis}

Data was subjected to the analysis of variance (ANOVA) using statistical analysis systems (SAS Version 9, 2000). Where the treatment effects found significant, mean separation was done using Least Significant Difference (LSD) test at 5\% level of significance. Correlation analysis was done using Pearson's simple correlation coefficients for some intended growth parameters of potato.

\section{RESULT}

Potato is influenced by many factors interacting together and independently. Among the factors plant nutrient 
like $\mathrm{N}$ fertilizer and intra row spacing are the major ones. In this study different level of nitrogen and intra row spacing had considerable influence on growth and growth parameters. Data collected for each parameter was analyzed and the result of analysis of variance for nitrogen, spacing and their interaction effect for main stem number, plant height, leaf area, Days to $50 \%$ flowering, shoot fresh weigh and total dry weight is presented in Table 2.

Table 2: Mean squares for main stem number, plant height, leaf area, days $50 \%$ flowering, shoot fresh weight, total dry weight.

\begin{tabular}{|c|c|c|c|c|c|c|c|}
\hline $\begin{array}{l}\text { Sources } \\
\text { of } \\
\text { variation }\end{array}$ & $\begin{array}{l}\text { Degree } \\
\text { of } \\
\text { freedom }\end{array}$ & $\begin{array}{l}\text { main stem } \\
\text { number, }\end{array}$ & $\begin{array}{l}\text { plant } \\
\text { height, }\end{array}$ & leaf area, & $\begin{array}{l}\text { Days to } 50 \% \\
\text { flowering, }\end{array}$ & $\begin{array}{l}\text { shoot fresh } \\
\text { weigh, }\end{array}$ & $\begin{array}{ll}\text { total dry } \\
\text { matter }\end{array}$ \\
\hline Rep & 2 & 1.81 & 74.1 & 0.17 & 327.26 & 9001.76 & 10025.62 \\
\hline $\mathrm{N}$ & 2 & $36.04 * *$ & $220.91 *$ & $11.23 * *$ & $1131.15^{* *}$ & $15167.96 * *$ & $23380.72 * *$ \\
\hline $\mathrm{S}$ & 2 & $29.04 * *$ & $43.1^{\mathrm{ns}}$ & $0.17^{\mathrm{ns}}$ & $158.93 *$ & $9425.24 * *$ & $14410.68 * *$ \\
\hline NXS & 4 & $3.04^{\mathrm{ns}}$ & $6.39^{\text {ns }}$ & $0.1^{\mathrm{ns}}$ & $8.93^{\text {ns }}$ & $396.9^{\text {ns }}$ & $903.38^{\text {ns }}$ \\
\hline Error 16 & & 3.98 & 36.68 & 0.18 & 36.34 & 799.32 & 1763.5 \\
\hline $\mathrm{Cv}$ & & 24 & 15.9 & 8.95 & 10.98 & 9.57 & 16.21 \\
\hline LSD & & 1.99 & 6.05 & 0.42 & 6.02 & 28.25 & 41.97 \\
\hline
\end{tabular}

R: replication $\quad \mathrm{N}$ : nitrogen $\mathrm{S}$ : space $\mathrm{CV}$ : correction factor LSD: least significant difference

Table 3: Effect of nitrogen and intra row spacing on Main steam, Plant height and Leaf area of potato

\begin{tabular}{llll}
\hline Nitrogen(kg/ha) & Main steam number & plant height & leaf area \\
\hline $\mathbf{0}$ & $6.33^{\mathrm{b}}$ & $32.52^{\mathrm{b}}$ & $3.56^{\mathrm{c}}$ \\
$\mathbf{6 9}$ & $8.22^{\mathrm{b}}$ & $39.71^{\mathrm{a}}$ & $4.77^{\mathrm{b}}$ \\
$\mathbf{1 3 8}$ & $10.33^{\mathrm{a}}$ & $42.02^{\mathrm{a}}$ & $5.79^{\mathrm{a}}$ \\
& & & \\
Intrarow spacing(cm) & & \\
$\mathbf{3 0}$ & $10.22^{\mathrm{a}}$ & $39.07^{\mathrm{a}}$ & $4.59^{\mathrm{a}}$ \\
$\mathbf{4 0}$ & $6.67^{\mathrm{b}}$ & $35.58^{\mathrm{a}}$ & $7.71^{\mathrm{a}}$ \\
$\mathbf{5 0}$ & $8^{\mathrm{b}}$ & $39.61^{\mathrm{a}}$ & $4.84^{\mathrm{a}}$ \\
LSD & 1.99 & 6.05 & 0.42 \\
$\mathbf{C V}$ & 24.05 & 15.9 & 8.95 \\
\hline
\end{tabular}

\subsection{Effect of nitrogen and intra row spacing on number of main stem.}

Significantly the highest main stem number (10.33) was recorded from $138 \mathrm{~kg} /$ ha of $\mathrm{N}$ fertilizer. But the lowest main stem number (6.33) was obtained from control treatment whereas the medium main stem number (8.22) was obtained from $69 \mathrm{~kg} /$ ha of $\mathrm{N}$ fertilizer(Table 3 ). This was due to the fact that the addition of $\mathrm{N}$ fertilizer was enhanced the growth and development of more number of stems of potato.

The main stem number $(10.33)$ recorded at $138 \mathrm{~kg} /$ ha of $\mathrm{N}$ fertilizer was significantly different from the main stem number (6.33) recorded at $69 \mathrm{~kg} / \mathrm{ha}$ of $\mathrm{N}$ fertilizer and the main stem number (8.22) recorded at control of $\mathrm{N}$ fertilizer whereas no significantly different between the main stem number (6.33) recorded at $69 \mathrm{~kg} / \mathrm{ha}$ of $\mathrm{N}$ fertilizer and the main stem number (8.22) recorded at control of $\mathrm{N}$ fertilizer. For the main stem number application of $138 \mathrm{~kg} / \mathrm{ha}$ of $\mathrm{N}$ fertilizer was recommended.

In case of intra row spacing significantly the highest number of main stem per plant (10.22) was recorded at the closer intra row spacing of $30 \mathrm{~cm}$ whereas the lowest number of stem per plant (6.67) was obtained at the medium intra row spacing of $40 \mathrm{~cm}$ (Table 3 ). This was due to the plant density was highest at the closer intra row spacing. Maximum numbers of main stem per plant obtain was significantly different from the main stem number (6.67) recorded at $40 \mathrm{~cm}$ in end in the closer intra row spacing. The main stem number $(10.22)$ recorded at $30 \mathrm{~cm}$ intra row spacing trarow spacing and the main stem number (8) recorded at $50 \mathrm{~cm}$ intrarow spacing whereas no significantly different between the main stem number (6.67) recorded at $40 \mathrm{~cm}$ intrarow spacing and the main stem number (8) recorded at $50 \mathrm{~cm}$ intrarow spacing. For the main stem number $30 \mathrm{~cm}$ intrarow spacing was recommended.

The number of main stem per plant was affected significantly $(\mathrm{p}<0.05)$ by the application of different rate of nitrogen and intra row spacingwhereas their interaction was none significantly $(p<0.05)$. This was due to the fact that the addition of $\mathrm{N}$ fertilizer was enhanced the growth and development of more number of stems of potato. The result of this current investigation is in agreement with the work of (Qadir, 1997) who found that number of stems per plant (4.44) was significantly higher when plants were get $\mathrm{N}$ fertilizer. 


\subsection{Effect of nitrogen and intra row spacing on plant height}

The highest plant height $(39.61 \mathrm{~cm})$ was obtained at the wider intra row spacing of $50 \mathrm{~cm}$ and this is not significantly different from the plant height obtained at $30 \mathrm{~cm}$ intra row spacing and $40 \mathrm{~cm}$ intra row spacing. On the other hand, the shortest plant height $(35.58 \mathrm{~cm}$ ) was observed at $40 \mathrm{~cm}$ intra row spacing (Table 3 ). This might be due to the presence of less competition for sunlight among plants grown at the wider intra row spacing. As a result of this study concluded that wider intra row spacing (lowered plant density) resulted in the highest plant height and recommended due to less cost of tuber seed.

In case of $\mathrm{N}$ fertilizer the highest plant height $(42.02 \mathrm{~cm})$ was obtained at $138 \mathrm{~kg} / \mathrm{ha}$ of $\mathrm{N}$ fertilizer, whereas medium plant height $(39.71 \mathrm{~cm})$ was observed at the $69 \mathrm{gk} / \mathrm{ha}$ of $\mathrm{N}$ fertilizer treatment and also the shortest plant height $(32.52 \mathrm{~cm}$ ) was observed at the control of $\mathrm{N}$ fertilizer (Table 3). This was due to the reason that addition of $\mathrm{N}$ fertilizer was improve soil nutrient and increased soil aeration for the growth of potato.

The plant height $(32.52 \mathrm{~cm})$ was recorded at control of $\mathrm{N}$ fertilizer was significantly different from the main stem number (39.71) recorded at $69 \mathrm{~kg} / \mathrm{ha}$ of $\mathrm{N}$ fertilizer and the plant height $(42.02)$ recorded at $138 \mathrm{~kg} / \mathrm{ha}$ of $\mathrm{N}$ fertilizer whereas non significantly different between the plant height $(39.71)$ recorded at $69 \mathrm{~kg} / \mathrm{ha}$ of $\mathrm{N}$ fertilizer and the plant height (42.02) recorded at $138 \mathrm{~kg} / \mathrm{ha}$ of $\mathrm{N}$ fertilizer. For the plant height application of $69 \mathrm{~kg} / \mathrm{ha}$ of $\mathrm{N}$ fertilizer was recommended due to less cost of fertilizer.

The plant height was affected significantly $(p<0.05)$ by the application of different rate of nitrogen whereas the intra row spacing and the interaction of nitrogen and intra row spacing were none significant $(p>0.05)$. This might be due to the presence of less competition for sunlight among plants grown at the wider intra row spacing. This is in agreement with the finding of (Zamilet al., 2010) who indicated that plant height was initially similar in all treatments but after 72 days the widely spaced plants became taller.

\subsection{Effect of nitrogen and intra row spacing on leaf area}

The largest leaf area $\left(7.71 \mathrm{~cm}^{2}\right)$ was obtained at the medium intra row spacing of $40 \mathrm{~cm}$ while the smallest leaf area $\left(4.59 \mathrm{~cm}^{2}\right)$ was recorded at the closer intra row spacing of $30 \mathrm{~cm}$ (Table 3). This is due to there was minimum competition at medium intra row spacing of plants that absorbed sufficiently available resources and more light and increased their photosynthetic efficiency that further increased the vegetative growth and ultimately resulted in increased leaf area. But at the wider intra row spacing there was excess height of potato and low leaf area

The result for leaf area was not significantly different between $(10.22)$ recorded at $30 \mathrm{~cm}$ intra row spacing, (6.67) recorded at $40 \mathrm{~cm}$ intra row spacing and (8) recorded at $50 \mathrm{~cm}$ intra row spacing. For the leaf area50 $\mathrm{cm}$ intra row spacing was recommended due to less of tuber seed.

In case of $\mathrm{N}$ the largest leaf area $\left(5.79 \mathrm{~cm}^{2}\right)$ was observed at $138 \mathrm{~kg} / \mathrm{ha}$ of $\mathrm{N}$ fertilizer. The medium leaf area $\left(4.77 \mathrm{~cm}^{2}\right)$ was observed at $69 \mathrm{~kg} / \mathrm{ha}$ of $\mathrm{N}$ fertilizer while the smallest leaf area $\left(3.56 \mathrm{~cm}^{2}\right)$ was recorded at the control treatment (Table 3). The leaf area was significantly different between (5.79) recorded at $138 \mathrm{~kg} / \mathrm{ha}$ of $\mathrm{N}$ fertilizer, (4.77) recorded at $69 \mathrm{~kg} / \mathrm{ha}$ of $\mathrm{N}$ fertilizer and (3.56) recorded at control of $\mathrm{N}$ fertilizer. For the leaf area $138 \mathrm{~kg} / \mathrm{ha}$ of $\mathrm{N}$ fertilizer, was recommended due to result of largest area.

Intra row spacing and the interaction of nitrogen and intra row spacing were none significantly $(p>0.05)$ and the nitrogen was significantly $(\mathrm{p}<0.05)$ affected the area of leaf per plant. This study was in agreement with (Burton et al ,1989), who indicated that nitrogen is essential for vegetative growth of potato such as increased leaf area that increase the photosynthetic efficiency of the plant treated to utilize other nutrients. In addition, indicated that the rate of leaf expansion is increased by increasing the application of nitrogen fertilizer.

Table 4: Effect of nitrogen and intra row spacing on Days to $50 \%$ flowering, Shoot fresh weight and Total dry mater of potato

\begin{tabular}{llll}
\hline Nitrogen(kg/ha) & Days to 50\% flowering, & shoot fresh weigh & total dry matter \\
\hline $\mathbf{0}$ & $44.33^{\mathrm{c}}$ & $253.91^{\mathrm{c}}$ & $211.67^{\mathrm{b}}$ \\
$\mathbf{6 9}$ & $53.78^{\mathrm{b}}$ & $296.69^{\mathrm{b}}$ & $245.86^{\mathrm{b}}$ \\
$\mathbf{1 3 8}$ & $66.67^{\mathrm{a}}$ & $335.99^{\mathrm{a}}$ & $319.59^{\mathrm{a}}$ \\
Intrarow spacing(cm & & \\
$\mathbf{3 0}$ & $52.44^{\mathrm{b}}$ & $264.68^{\mathrm{b}}$ & $225.98^{\mathrm{b}}$ \\
$\mathbf{4 0}$ & $52.56^{\mathrm{b}}$ & $292.69^{\mathrm{b}}$ & $247.61^{\mathrm{b}}$ \\
$\mathbf{5 0}$ & $59.78^{\mathrm{a}}$ & $329.22^{\mathrm{a}}$ & $303.52^{\mathrm{a}}$ \\
$\mathbf{L S D}$ & 6.02 & 28.25 & 41.97 \\
$\mathbf{C V}$ & 10.98 & 9.57 & 16.21 \\
\hline
\end{tabular}

\subsection{Effect of nitrogen and intra row spacing on days to $50 \%$ flowering}

The earliest days to $50 \%$ of flowering was observed at the closer intra row spacing of $30 \mathrm{~cm}$ and $40 \mathrm{~cm}$. Whereas, days to $50 \%$ of flowering was prolonged in $50 \mathrm{~cm}$ intra row spacing (Table 4). Days to $50 \%$ of flowering was delayed by about 10 days in the wider intra row spacing of $50 \mathrm{~cm}$ as compared to the closest intra row spacing of $30 \mathrm{~cm}$. This could be due to higher competition of plants for resources in the closer intra row spacing that lead the 
plants to stress and ultimately the plants flowering parade was prolonged instead of vegetative growth.

Days to $50 \%$ flowering $(59.78)$ was recorded at $50 \mathrm{~cm}$ intra row spacing was significantly different from (52.56) recorded at $40 \mathrm{~cm}$ intra row spacing and $(52.44)$ recorded at $30 \mathrm{~cm}$ intra row spacing whereas no significantly different between $(52.56)$ recorded at $40 \mathrm{~cm}$ intra row spacing and the main stem number $(52.44)$ recorded at $30 \mathrm{~cm}$ intra row spacing.

For the main stem number days to $50 \%$ flowering $30 \mathrm{~cm}$ intra row spacing and $40 \mathrm{~cm}$ intra row spacing was recommended due to shortened time. In case $\mathrm{N}$ fertilizer according to the result of the present investigation, it was observed that which an increase in the application of nitrogen of flowering was delayed correspondingly. The highest mean of days to flowering for $138 \mathrm{~kg} / \mathrm{ha}$ of nitrogen (66.67day). These showed the longer time the plant took to flower, because of the fact that excess nitrogen prolonged the vegetative phase of growth and delayed flowering. Whereas the lowest mean of days to flowering for $69 \mathrm{~kg} / \mathrm{ha}$ of nitrogen ( 53.78 day) showed the shorter time the plant took to flower, because of the fact that less nitrogen shortened the vegetative phase of growth and facilitated flowering. The earliest days to $50 \%$ flowering (44.33 days) was observed at no $\mathrm{N}$ fertilizer (control) treatment and this was not significantly different from potato plant. This could be due to the fact that absence of $\mathrm{N}$ fertilizer created stress on the plant due to lack of nutrient and aeration during its active growth stage that affected the plant growth and brought early flowering.

A day to $50 \%$ flowering was significantly different between $(69.67)$ recorded at $138 \mathrm{~kg} / \mathrm{ha}$ of $\mathrm{N}$ fertilizer, (53.78) recorded at $69 \mathrm{~kg} / \mathrm{ha}$ of $\mathrm{N}$ fertilizer and (44.3) recorded at control of $\mathrm{N}$ fertilizer. Forthe day to $50 \%$ flowering control of $\mathrm{N}$ fertilizer was recommended due to shortened time.

Application of nitrogen, and intra row spacing were significantly $(\mathrm{p}<0.05)$ and their interaction was none significantly $(p>0.05)$ influenced the days required for flowering. This may be justifiable because of the fact that excess nitrogen prolonged the vegetative phase of growth and delayed flowering. This was in agreement with (Ahmed et al ,2000), who reported that nitrogen showed the strongest influence on ground cover early and late in the season and also lengthens the growing period that results in delayed flowering.

\subsection{Effect of nitrogen and intra row spacing on Shoot fresh weight}

Significantly the highest shoot fresh weight (335.99 gm.) was recorded at $138 \mathrm{~kg} / \mathrm{ha}$ of N fertilizer. But the lowest shoot fresh weight $(253.91 \mathrm{gm}$.) was obtained at control treatment whereas the medium shoot fresh weight $(296.69 \mathrm{gm}$.) was obtained at $69 \mathrm{~kg} / \mathrm{ha}$ of $\mathrm{N}$ fertilizer (Table 4). This was due to the fact that the addition of $\mathrm{N}$ fertilizer was enhanced the growth and development of potato that increase shoot fresh weight of potato.

As a result of this study concluded that the Shoot fresh weight of potato was significantly higher for plants when plants were get $\mathrm{N}$ fertilizer.

The shoot fresh weight (335.99) recorded at $138 \mathrm{~kg} / \mathrm{ha}$ of $\mathrm{N}$ fertilizer was significantly different from the shoot fresh weight (296.69) recorded at 69kg/ha of N fertilizer, shoot fresh weight (253.91) recorded at control of $\mathrm{N}$ fertilizer whereas no significantly different between the shoot fresh weight (296.69) recorded at $69 \mathrm{~kg} / \mathrm{ha}$ of N fertilizer and the shoot fresh weight (253.91) recorded at control of $\mathrm{N}$ fertilizer. For the shoot fresh weight application of $138 \mathrm{~kg} / \mathrm{ha}$ of $\mathrm{N}$ fertilizer was recommended.

In case of intra row spacing significantly the highest Shoot fresh weight $(329.22 \mathrm{gm}$.) was recorded at the wider intra row spacing of $50 \mathrm{~cm}$ whereas the lowest Shoot fresh weight $(264.68 \mathrm{gm}$.) was obtained at the lowest intra row spacing of $30 \mathrm{~cm}$ (Table 3). This was due to in the wider intra row spacing there could be minimum competition among plants for space and resources and also better plant exposure for high radiation interception that increased the photosynthetic efficiency of the plant and finally resulting in increased Shoot fresh weight of potato.

Shoot fresh weight (329.22) recorded at $50 \mathrm{~cm}$ intra row spacing was significantly different from shoot fresh weight (292.69) recorded at $40 \mathrm{~cm}$ intra row spacing and shoot fresh weight (264.68) recorded at 30cm intra row spacing whereas no significantly different between shoot fresh weight (292.69) recorded at $40 \mathrm{~cm}$ intra row spacing and the shoot fresh weight $(269.68)$ recorded at $30 \mathrm{~cm}$ intra row spacing. For the shoot fresh weight $50 \mathrm{~cm}$ intra row spacing was recommended due to shortened time.

The shoot fresh weight of potato was affected significantly $(\mathrm{p}<0.05)$ by the application of different rate of nitrogen and intra row spacing. Whereas their interaction was affected none significantly $(p>0.05)$. The result of this current investigation is in agreement with the work of (Qadir, 1997) who found that Shoot fresh weight potato (259.44gm.) was significantly higher when plants were get $\mathrm{N}$ fertilizer. As a result of this study concluded that the Shoot fresh weight of potato was significantly higher for plants when plants were get $\mathrm{N}$ fertilizer and also agrees with the finding of woldemariam et al..(2015) who mentioned that The highest fresh biomass yield (125.18g plant-1) was obtained from the combined effect of $138 \mathrm{~kg} \mathrm{~N}$ ha-1 and wider intra-row spacing of $15 \mathrm{~cm}$ in onion The result of this study is supported by Halvorson et al. (2002) who reported that higher $\mathrm{N}$ application rates leadto rapid leaf area development, prolonged the life of leaves, improved leaf area, and increased overall crop assimilation which in turn contribute to the increased fresh biomass yield of the crop. 


\subsection{Effect of nitrogen and intra row spacing on total dry weight}

The highest total dry weight was recorded from $138 \mathrm{~kg} / \mathrm{ha} \mathrm{N}$ fertilizer which is $319.59 \mathrm{gm}$ this rate have significant effect on total dry weight when compared to others. While the lowest total dry weight, $(211.67 \mathrm{gm}$. $)$ was obtained from control treatment whereas the medium total dry weight $(245.86 \mathrm{gm}$.) was obtained at $69 \mathrm{~kg} / \mathrm{ha}$ of $\mathrm{N}$ fertilizer. (Table 4). This was due to the fact that the addition of $\mathrm{N}$ fertilizer was enhanced the growth and development of potato that increase total dry weight of potato.

The total dry weight (319.59) recorded at $138 \mathrm{~kg} / \mathrm{ha}$ of $\mathrm{N}$ fertilizer was significantly different from the total dry weight (245.86) recorded at $69 \mathrm{~kg} / \mathrm{ha}$ of $\mathrm{N}$ fertilizer and the total dry weight (211.67) recorded at control of $\mathrm{N}$ fertilizer whereas none significantly different between the total dry weight $(245.86)$ recorded at $69 \mathrm{~kg} / \mathrm{ha}$ of $\mathrm{N}$ fertilizer and the total dry weight (211.67) recorded at control of $\mathrm{N}$ fertilizer. For the main stem number application of $138 \mathrm{~kg} / \mathrm{ha}$ of $\mathrm{N}$ fertilizer was recommended.

In case of intra row spacing significantly the highest total dry weight $(303.52 \mathrm{gm}$.) was recorded at the wider intra row spacing of $50 \mathrm{~cm}$ whereas the lowest total dry weight $(225.98 \mathrm{gm}$.) was obtained at the lowest intra row spacing of $30 \mathrm{~cm}$ (Table 2). This was due to in the wider intra row spacing cause minimum competition among plants for space and resources and also better plant exposure for high radiation interception that increased the photosynthetic efficiency of the plant and finally resulting in increased total dry weight of potato.

Total dry weight $(303.52)$ recorded at $50 \mathrm{~cm}$ intra row spacing was significantly different from A total dry weight (247.61) recorded at $40 \mathrm{~cm}$ intra row spacing and total dry weight $(225.98)$ recorded at $30 \mathrm{~cm}$ intra row spacing whereas none significantly different between total dry weight $(247.61)$ recorded at $40 \mathrm{~cm}$ intra row spacing and total dry weight $(225.98)$ recorded at $30 \mathrm{~cm}$ intra row spacing. For the total dry weight $50 \mathrm{~cm}$ intra row spacing was recommended.

The total dry weight of potato was affected significantly $(p<0.05)$ by the application of different rate of nitrogen and intra row spacing. Whereas their interaction was affected none significantly $(\mathrm{p}>0.05)$. and this was in agreement with (Horton, 1987) who stated that in potato total dry weight production is increased with level of nitrogen increasing. Increasing intra raw spacing also increased the total dry weight production and the highest mean $(303.52 \mathrm{gm}$.)Was recorded with $50 \mathrm{~cm}$ intra row spacing but interaction of nitrogen fertilizer and intra row spacing should non-significant $(\mathrm{p}>0.05)$ effect on total dry weight production statistically. This finding is also supported by woldemariam et al,.(2015 The highest dry biomass yield (30.39g plant-1) was obtained from the combined effect of $138 \mathrm{~kg} \mathrm{~N}$ ha- 1 and wider intra-row spacing of $15 \mathrm{~cm}$, which was about $217.52 \%$ higher over the dry biomass yield per plant recorded from null $\mathrm{N}$ fertilizer application and closer intra-row spacing of $7.5 \mathrm{~cm}$ on onion crop

\section{ACKNOWLEDGEMENT}

Above all, I would like to thanks God a debt of praise for his presence with me in all ups and downs. Next I would like to express my great thanks to Wolaita Sodo University College of Agriculture and particularly Department of horticulture to provide conducive environment to conduct the research . special thanks goes to my family specially my mother Almaz Hayle

\section{REFERENCES}

Ahmed,I,S.HassainA.AbdurRab and N.Ali, 2000. Yield dynamic in potation relation to variety and row spacing. Burton, W.G., 1989. The Potato. 3rd Edn., Longman Scientific and Technical Publisher, Exssex, R., A. Decoteau, A. hearth and H. Graham, 1994. Plant special arrangement affects growth, yield and distribution of Cayenne Peppers.

FAO, 2008.International year of potato.Food and Agriculture Organization of the United Nations, Rome, Italy. http://www.potato2008.org/en/index.html.

Horton, D., 1987. Potato production, marketing and programs for developing countries.

Oliveira C.A.D.S., 2000. Potato crop growth as affected by Nitrogen and plant density.

Qadir, 1997. Effect of earthing -up at different stages of growth on the yield of different potato cultivars under the soil and climatic conditions of peshawar. Crop husbandry section of Pakistan, Pashawar, Pakistan.

Visker, M., 2005.Association between late blight resistance and foliage maturity type in potato-physiological and genetic studies.

Zamilet, M.F., M.M. Rahman, M.G. Robbani and T. Khatun, 2010.Combined effect of nitrogen and plant spacing on the growth and yield of potato with economic performance. 
$\mathrm{N}$ :

$\mathrm{PH}^{\mathrm{H}}$

nitrogen

\section{LIST OF ABBREVIATION}

BOARD: $\quad$ Bureau of Agricultural and Rural Development

m.a.s.l: meter above sea level

Kg: $\quad$ kilogram

M: meter

LSD: $\quad$ Least significant difference

G: $\quad$ gram

CM: centimeter

$\mathrm{M}^{2:} \quad$ meter square

Ha: $\quad$ hectare

\section{List of tables 1}

Table 1.Treatment combination were used in the experiment..........................................................................12 Table 2: Mean squares for main stem number, plant height, leaf area, days $50 \%$ flowering, shoot fresh weight, total dry weight.

Table 3: Effect of nitrogen and intra row spacing on growth of potato

APPENDICES

Table: 1 Analysis of variance for Main stem number

\begin{tabular}{llllll}
\hline Source of Variation & Degree of freedom & Sum square & Mean sum square & F value & Pr $>$ f \\
\hline Rep & 2 & 3.63 & 1.81 & 0.46 & 0.6419 \\
N & 2 & 72.07 & 36.04 & 9.05 & 0.0023 \\
S & 2 & 58.07 & 29.04 & 7.29 & 0.0056 \\
NXS & 4 & 12.15 & 3.04 & 0.76 & 0.5646 \\
Error & 16 & 63.7 & 3.98 & & \\
Total & 26 & 209.63 & & & \\
\hline
\end{tabular}

$\mathrm{CV}=11.4 \%$

Table: 2 Analysis of variance for plant height

\begin{tabular}{|c|c|c|c|c|c|c|c|}
\hline $\begin{array}{l}\text { Source of } \\
\text { Variation }\end{array}$ & $\begin{array}{l}\text { Degree } \\
\text { freedom }\end{array}$ & of & Sum square & $\begin{array}{l}\text { Mean } \\
\text { square }\end{array}$ & sum & F value & $\operatorname{Pr}>$ \\
\hline Rep & 2 & & 149.79 & 74.9 & & 2.04 & 0.1623 \\
\hline $\mathrm{N}$ & 2 & & 441.81 & 220.91 & & 6.02 & 0.0112 \\
\hline $\mathrm{S}$ & 2 & & 86.21 & 43.1 & & 1.17 & 0.3341 \\
\hline NXS & 4 & & 25.56 & 6.39 & & 0.17 & 0.9484 \\
\hline Error & 16 & & 586.98 & 36.69 & & & \\
\hline Total & 26 & & 1290.35 & & & & \\
\hline
\end{tabular}

CV: 15.90

Table :3 Analysis of variance for leaf area

\begin{tabular}{|c|c|c|c|c|c|c|c|}
\hline $\begin{array}{l}\text { Source of } \\
\text { Variation }\end{array}$ & $\begin{array}{l}\text { Degree } \\
\text { freedom }\end{array}$ & of & Sum square & $\begin{array}{l}\text { Mean } \\
\text { square }\end{array}$ & sum & F value & $\operatorname{Pr}>f$ \\
\hline Rep & 2 & & 0.35 & 0.17 & & 0.98 & 0.4 \\
\hline $\mathrm{N}$ & 2 & & 22.45 & 11.13 & & 63.28 & $<.0001$ \\
\hline S & 2 & & 0.34 & 0.17 & & 0.95 & 0.4087 \\
\hline NXS & 4 & & 0.41 & 0.1 & & 0.57 & 0.69 \\
\hline Error & 16 & & 2.84 & 0.18 & & & \\
\hline Total & 26 & & 26.38 & & & & \\
\hline
\end{tabular}


Table: 4 Analysis of variance for date of flowering

\begin{tabular}{|c|c|c|c|c|c|c|c|}
\hline $\begin{array}{l}\text { Source of } \\
\text { Variation }\end{array}$ & $\begin{array}{l}\text { Degree } \\
\text { freedom }\end{array}$ & of & Sum square & $\begin{array}{l}\text { Mean } \\
\text { square }\end{array}$ & sum & F value & $\operatorname{Pr}>f$ \\
\hline Rep & 2 & & 654.52 & 9 & & 5.69 & 0.0136 \\
\hline $\mathrm{N}$ & 2 & & 2262.3 & 31.12 & & 15.53 & 0.0002 \\
\hline $\mathrm{S}$ & 2 & & 317.58 & 4.37 & & 8.17 & 0.0036 \\
\hline NXS & 4 & & 35.7 & 0.25 & & 0.51 & 0.7277 \\
\hline Error & 16 & & 581.48 & & & & \\
\hline Total & 26 & & 3851.85 & & & & \\
\hline
\end{tabular}

Cv:10.98

Table:5 Analysis of variance for fresh weight

\begin{tabular}{|c|c|c|c|c|c|c|c|}
\hline $\begin{array}{l}\text { Source of } \\
\text { Variation }\end{array}$ & $\begin{array}{l}\text { Degree } \\
\text { freedom }\end{array}$ & of & Sum square & $\begin{array}{l}\text { Mean } \\
\text { square }\end{array}$ & sum & $F$ value & $\operatorname{Pr}>f$ \\
\hline Rep & 2 & & 18003.51 & 9001.76 & & 11.26 & 0.0009 \\
\hline $\mathrm{N}$ & 2 & & 30335.37 & 15167.69 & & 18.98 & $<.0001$ \\
\hline S & 2 & & 18850.49 & 9425.24 & & 11.79 & 0.0007 \\
\hline NXS & 4 & & 1587.72 & 396.93 & & 0.5 & 0.7386 \\
\hline Error & 16 & & 12789.19 & 799.32 & & & \\
\hline Total & 26 & & 81566.28 & & & & \\
\hline
\end{tabular}

Cv: 9.57

Table: 6 Analysis of variance for dry weight

\begin{tabular}{|c|c|c|c|c|c|c|c|}
\hline $\begin{array}{l}\text { Source of } \\
\text { Variation }\end{array}$ & $\begin{array}{l}\text { Degree } \\
\text { freedom }\end{array}$ & of & Sum square & $\begin{array}{l}\text { Mean } \\
\text { square }\end{array}$ & sum & $\mathrm{F}$ value & $\operatorname{Pr}>f$ \\
\hline Rep & 2 & & 20051.24 & 10025 & & 5.69 & 0.0136 \\
\hline $\mathrm{N}$ & 2 & & 54761.44 & 27380.72 & & 15.53 & 0.0002 \\
\hline $\mathrm{S}$ & 2 & & 28821.35 & 14410.68 & & 8.17 & 0.0036 \\
\hline NXS & 4 & & 3613.51 & 903.38 & & 0.51 & 0.7277 \\
\hline Error & 16 & & 28216.03 & 1763.5 & & & \\
\hline Total & 26 & & 135463.58 & & & & \\
\hline
\end{tabular}

Cv: 16.21 